\title{
Globalização e Multilingualismo no Brasil Competência Linguística e o Programa Ciência Sem Fronteiras
}

\section{Globalization and Multilingualism in Brazil}

\section{Linguistic Competence and the Science Without Borders Program}

Renata Archanjo

Universidade Federal do Rio Grande do Norte

Natal - Rio Grande do Norte / Brasil

RESUMO: A contemporaneidade celebra a sociedade do conhecimento e da informação. $\mathrm{O}$ conhecimento científico e tecnológico mobiliza e alimenta sua produção, consumo e progresso. Nesse cenário, o "mercado" linguístico cresce em importância. Globalizar e internacionalizar são palavras de ordem na sociedade atual e, nela, a promoção de uma educação multilíngue assume uma preponderância estratégica. Este texto problematiza esse cenário e questiona se há, no Brasil, uma política linguística que favoreça uma educação multilíngue, para que objetivos como a internacionalização e o incremento da produção científica e tecnológica no país tornem-se uma realidade efetiva. Os dados apresentados são parte de uma pesquisa em andamento sobre as competências linguísticas de estudantes de graduação participantes do Programa Ciência sem Fronteiras. Os dados apontam para a predominância do sistema privado de educação sobre o público e para a busca de estratégias individuais na aprendizagem de línguas estrangeiras.

PALAVRAS-CHAVE: globalização; multilingualismo; políticas linguísticas; ensino e aprendizagem de língua estrangeira; Ciência sem Fronteiras; internacionalização; Brasil.

ABSTRACT: In contemporary and urban societies, knowledge and information are featured prominently. Scientific and technological knowledge drives the production, consumption and progress of societies. In this scenario, languages

*renaarchanjo@gmail.com 
and the "linguistic market" appear as important issues and are crucial for human interaction as well as for political, educational and economic achievements. Globalization and internationalization are key words in the configuration of this kind of society. That is why a multilingual education is a strategic orientation. This paper discusses linguistic policies that could favour a multilingual education in Brazil, so that broader objectives, such as the internationalization and the enhancement of scientific and technological production and innovation, become a reality. The data presented in the paper are part of a broader research on the linguistic competence of Brazilian undergraduate students in international mobility programs. Preliminary results point out the predominance of the private educational system rather than the public, and the increase of individual strategies, in the process of learning a foreign language.

KEYWORDS: globalization; multilingualism; linguistic policies; foreign language teaching and learning; Science without Borders; internationalisation; Brazil.

\section{Introdução}

O fenômeno da globalização ampliou e transformou as relações sociais, no mundo. Definida por Blommaert (2010, p.13) como "a intensificação dos fluxos de capital, bens, indivíduos, imagens e discursos mundo afora, impulsionados pelas inovações tecnológicas principalmente no campo da mídia, da informação e da tecnologia de comunicação, resultando em novos padrōes de atividade global, de organização comunitária e de cultura (Tradução livre)", a globalização maximizou as relações interpessoais em muitas esferas da atividade humana, diluindo fronteiras e aproximando indivíduos, línguas e culturas.

A sociedade globalizada (MOITA LOPES, 2006, 2013; KUMARADIVELU, 2006; RAMPTON, 2006; BLOMMAERT, 2010) tem, assim, como uma de suas características, o fato de promover e intensificar diferentes tipos de relação (econômica, social, cultural etc.). Dados os avanços tecnológicos nas áreas da comunicação e dos transportes, espaços, tempos e fronteiras tornaram-se conceitos permeáveis. As sociedades de conexões rápidas nas quais vivemos, na contemporaneidade, inscrevem-se em cronotopos, nos quais tempo e espaço são valores fugazes e transitórios (BAKHTIN, 1990; HARVEY, 1989), diferentemente das sociedades tradicionais, nas quais as relações sociais se davam em tempo e espaço situados e definidos geograficamente (GIDDENS, 1990).

Para além da modernidade, ou melhor, na continuação dela, identificamos como suas características a supressão do tempo, a globalização 
do espaço, a descontinuidade das tradições e a singularidade do indivíduo. Quer seja conceituando-o como modernidade tardia (GIDDENS, 1990), pósmodernidade (JAMESON, 1991) ou como modernidade líquida (BAUMAN, 2001), o tempo presente é fluido e se constrói sobre verdades relativas e cambiantes. Estas verdades se defendem e se autolegitimam pela justificativa de que é seu poder de modificação e de adaptação rápida às necessidades urgentes do ser humano e do mundo que as tornam adequadas ao seu tempo.

A globalização, uma das principais faces da contemporaneidade, está na economia regulada por mercados mundiais; está no modo de vida dos indivíduos, em seus costumes e em suas práticas culturais. Está também nas formas de comunicação, nas línguas e nas transformaçōes dos padrōes linguísticos: sociedades globalizadas, cidades globais, cidadãos do mundo são também sociedades, cidades e indivíduos multilíngues. De forma não menos significativa, a globalização está também na produção do conhecimento que, mesmo que local, deve estar também em rede, para ser global.

Usando a globalização e o multilingualismo como conceitos guarda-chuva, apresento a seguir algumas esferas nas quais a observação das transformações decorrentes destas duas perspectivas nos permite discutir o tema central deste trabalho: políticas linguísticas no Brasil. São apresentados dados de pesquisa em andamento sobre as competências linguísticas de alunos brasileiros de graduação participantes do programa de mobilidade Ciência sem Fronteiras. A partir dos resultados apresentados, objetiva-se discutir em que medida as políticas linguísticas brasileiras e as iniciativas voltadas para a internacionalização do país favorecem uma educação multilíngue que se coloque como alternativa para transformar e impulsionar o ensino superior no país.

\section{A globalização}

A globalização transformou os fluxos migratórios que caracterizam a mobilidade social, no mundo. Diferentemente das diásporas clássicas, nas quais indivíduos, grupos e etnias deslocam-se e relocam-se, ou por subordinação a sistemas coloniais, por escravidão, por guerras e/ou até mesmo por desastres naturais (HALL, 2008), os novos migrantes da sociedade contemporânea têm motivações mais pontuais. As relações globalizadas movem e criam, não apenas as condições, mas igualmente a necessidade de sujeitos supostamente integrados no mundo. Os novos fluxos migratórios não necessariamente provocam, como nas diásporas históricas, a ruptura dos vínculos de origem dos migrantes. Para os novos migrantes, 
reais ou virtuais, voluntários ou involuntários, temporários ou não, legais ou ilegais, a mobilidade acontece motivada por interesses das mais diversas naturezas - pessoais, profissionais, econômicos, políticos, educacionais - e define-se como uma estratégia de transformação em fluxo contínuo e não necessariamente de ruptura e recomeço.

Assim, do fim do século XX para o início do século XXI, observamos que as migrações transnacionais e os novos fluxos de migrantes em circulação modificaram a demografia das cidades, sobretudo das grandes metrópoles, e criaram um cenário de superdiversidade (VERTOVEC, 2007; BLOMMAERT, 2010; BLOMMAERT \& BACKUS, 2011; BLOMMAERT \& RAMPTON, 2011) social (étnico, racial, urbano), mas também linguístico. Indivíduos e sociedades inteiras acreditam, de forma cada vez mais categórica, que a dinâmica da mobilidade que favorece as experiências multiculturais e o intercâmbio de conhecimentos nos mais diversos campos, observada de um modo positivo e propositivo, é a chave para o aumento da produtividade e para o sucesso de, cada vez mais, maior número de atividades humanas, no mundo globalizado em que vivemos.

Pelas consequências que dela decorrem, a globalização também transformou a comunicação em suas diversas formas. Para além, é claro, da multimodalidade nas formas de comunicação e da multiplicidade de meios de comunicação (em rede, em tempo real), a importância da diversidade linguística cresce no mundo. A possibilidade de se comunicar em mais de uma língua de modo ativo (na fala ou na escrita) ou de modo passivo (pela leitura ou pela compreensão oral) é o que se conceitua como multilingualismo (WEI, 2008) ou, segundo a tradição francesa, de plurilinguismo (BEACCO, 2008) - embora diferenças teóricas entre estes dois modos de conceituação produzam lentes que fazem com que olhemos para nosso objeto de estudo de modos diversos, e sobre isto trataremos mais adiante. De todo modo, o conhecimento, domínio e uso de várias línguas, na sociedade contemporânea, ganha um papel de preponderância, tanto no nível individual, quanto no nível da sociedade, em geral. Como define Pierre Bourdieu (1991), a linguagem é uma forma de capital, só que simbólico. Como tal é um recurso que estabelece relações de poder e por isso se apresenta de modo desigual na sociedade. Este capital simbólico adquire mais valor quando é legitimado por grupos de dominância social (grupos que também podem ser Estados-nações), como também pode ser associado a outras formas de capital (social e/ou econômico), fazendo assim, por sua vez, aumentar o valor de quem 
o domina. Para Bourdieu, a legitimação de uma língua (ou linguagem, como prática social) acontece por meio das instituições de Estado e por meio da educação. A educação é central para a reprodução social e cultural do capital simbólico e para a imposição de uma dada ordem simbólica.

Assim, a competência de poder comunicar em várias línguas pode ser também considerada uma mercadoria, um bem de consumo que interfere na cadeia produtiva de outros bens de consumo. Dominar várias línguas é um diferencial que agrega valor a quem tem esta competência (CENOZ, 2013), sobretudo se o conhecimento é o da língua que domina as relações interpessoais e institucionais, mundialmente. Por conseguinte, considerando a língua mais do que um meio de comunicação, um conhecimento multilíngue torna-se um elemento essencial para a promoção dos ideais caros ao mundo neoliberal e globalizado. O neoliberalismo é assumido, neste texto, como a teoria políticoeconômica que promove as práticas de livre mercado e de livre comércio por meio das açōes empreendedoras individuais com vistas ao bem estar social comum. $\mathrm{O}$ 'capital financeiro' ou o 'mercado' é o grande regulador das atividades humanas e cabe ao Estado garantir, apenas, as condições ideais para seu desenvolvimento. Segundo Harvey, neste contexto, "o papel do Estado é criar e preservar uma estrutura institucional apropriada a essas práticas” (2008, p. 12).

O neoliberalismo e a globalização correspondem a uma mudança paradigmática nos sistemas de produção e consumo das sociedades, visando mais lucro e acumulação de bens. Podem ser explicados do ponto de vista da lógica da produção e do ponto de vista das políticas de Estado. Do ponto de vista da primeira, a transformação da sociedade industrial (fordista) para uma sociedade pós-industrial ocorre pelas possibilidades criadas pelo campo da eletrônica e da informática na produção, circulação e comercialização dos bens de consumo (que podem ser materiais e imateriais). Do ponto de vista político, o efeito que se cria é o enfraquecimento do Estado no que se refere à promoção do bem-estar social em favor de um Estado que tem na promoção do mercado a finalidade das ações que desenvolve.

Em ambos os casos, a comunicação é central para o funcionamento do mercado (HELLER, 2007) e assim, nesse cenário, o mercado linguístico cresce em importância, em relevância e o ensino de línguas estrangeiras passa a ocupar um lugar de centralidade. Recrudesce o interesse pelas línguas - a sua, a do outro, a minha, a nossa - na medida em que, com ela (ou com elas), nas suas mais diversificadas formas e modalidades, podemos, além de atribuir sentido ao mundo, agir no mundo. Esses sentidos passam ao largo 
de uma ideologia ingênua, para a qual o reconhecimento e a valorização da diversidade linguística e cultural da humanidade seriam sinais de mútua compreensão e, portanto, de aceitação das diferenças. Tais sentidos estão muito mais facilmente encharcados pela ideologia das forças do mercado globalizado, para o qual a língua é também poder. Assim, não parece estranho termos, atualmente, a dominância linguística de uma única língua no cenário mundial - o inglês - se considerarmos que esta é a língua da economia, das relações internacionais, das redes virtuais, do entretenimento de massa, da ciência e da tecnologia. Entretanto, mesmo com todo este alcance, a língua inglesa (como primeira língua), curiosamente, não é nem a língua mais falada do planeta, nem a mais antiga, por exemplo. Se o protagonismo, hoje, é o da língua inglesa, não podemos esquecer que esse papel de centralidade já foi, também, desempenhado por outras línguas coloniais. Mesmo tendo perdido espaço para o inglês, essas outras línguas (como o francês, o espanhol e o próprio português), ainda têm seus centros de domínio e, não por acaso, esses empreendem ações sistemáticas de promoção, divulgação e manutenção de suas comunidades linguísticas por meio de associações, grupos, comunidades e redes, em todo o mundo, dada a força que tem a língua na construção das relaçôes sociais, identitárias e ideológicas. Construímos e compartilhamos ideologias sobre a língua assim como qualquer outra ideologia. E nos servimos delas para atuarmos no mundo social.

A globalização, por isso, também afeta, diretamente, o campo das políticas linguísticas. $\mathrm{Na}$ medida em que as línguas passam a ser um meio para viabilizar oportunidades de crescimento pessoal, econômico e social no mundo globalizado, seu valor como mercadoria cresce exponencialmente. Governos e comunidades internacionais organizadas (sendo a União Europeia, um exemplo) trabalham na promoção de políticas linguísticas que possam servir aos propósitos dos membros de sua comunidade, promovendo o crescimento econômico e a transformação social por meio da educação (não apenas formal, mas linguística, igualmente), da possibilidade de mobilidade e da empregabilidade nos países membros. A comunicação em diferentes línguas é essencial para atingir estes objetivos.

No contexto do mundo globalizado, as políticas linguísticas atuam basicamente em duas grandes frentes: na defesa da(s) língua(s) pátria(s) como bem cultural e simbólico de uma identidade nacional e na promoção do multilingualismo como bem de consumo. Mesmo na defesa de uma política multilíngue, no geral, em muitas sociedades, a adoção de uma língua 
franca é valorizada como o componente essencial para impulsionar o ideal de transformação e progresso (COTS; LLURDA \& GARRETT, 2014). Consideramos políticas linguísticas as normas e regras adotadas para a gestão das práticas de linguagem, por indivíduos, desde o nível governamental e supranacional, passando por toda uma gama de instituiçôes (educacionais, religiosas, militares) e domínios como a mídia e o mundo corporativo dos negócios, chegando até ao nível familiar (SPOLSKY, 2009, 2012). Assim, quando os membros de uma família, cujos progenitores são indivíduos falantes de línguas diferentes, decidem que seus filhos serão criados em um meio bilíngue, para que ambas as línguas de comunicação da família sejam preservadas e compartilhadas por todos os seus membros, ela revela, com esta decisão, um modelo de gestão próprio, embutido de ideologias e valores particulares, que representam uma ação no campo da política linguística. Quando um Estado-nação decide que a língua de escolarização da população será uma língua diferente $\mathrm{da}(\mathrm{s})$ falada(s) nativamente em seu território, esta ação reflete as políticas linguísticas adotadas pelo governo para toda aquela sociedade. No nível individual, familiar, institucional ou da sociedade, em geral, uma perspectiva bi ou multilíngue afeta a vida das pessoas. Os interesses podem ser os mais diversos. Desde a preservação de uma herança linguística, à adoção de uma língua colonizadora, ou à promoção de uma ou mais línguas que possuam valor de mercado, políticas linguísticas respondem a contextos sociais e históricos e impactam nas perspectivas de transformação das sociedades. O que chamo aqui de línguas que possuem valor de mercado são aquelas tidas como língua franca, as quais são adotadas, muitas vezes, supra nacionalmente. São línguas implementadas como meio de instrução, como língua internacional para as relações comerciais, esportivas, políticas e também acadêmicas. A língua inglesa é o melhor exemplo, atualmente, de língua franca adotada em todos os contextos citados, em muitas sociedades.

Não se pode esquecer, ademais, que como a proficiência em uma ou mais língua estrangeira não é um bem que se produza e se compre pronto e acabado, pois implica uma ação processual de aprendizagem - embora seja um bem que se venda na forma dos serviços prestados por indivíduos ou instituiçóes que ensinam línguas - esta dinâmica afeta também o campo do ensino. E esta tem sido outra das transformações que a globalização tem proporcionado, na contemporaneidade. Em defesa da competitividade e da produtividade, governos e instituiçôes em países do mundo todo têm investido no ensino de línguas estrangeiras. Este investimento, visando a internacionalização do 
ensino, sobretudo do ensino superior, é hoje, uma realidade mundial. Por conseguinte, o impacto das políticas linguísticas, no mundo globalizado, reflete-se, igualmente, nas políticas educacionais e nos modelos de ensino.

Estudos recentes sobre o ensino e aprendizagem de línguas, a formação e o treinamento do professor de línguas, bem como das metodologias de ensino têm procurado responder aos desafios postos pela globalização no campo da linguagem (GARCIA \& SYLVAN, 2011; GARCIA \& FLORES, 2012; KRAMSCH, 2014; LO BIANCO, 2014; MCNAMARA, 2011; OLIVEIRA, 2014). Estas transformações produzem efeitos na circulação das línguas estrangeiras, no valor que se atribui a uma ou mais línguas ou a algumas variaçôes linguísticas sobre outras, nos usos das diferentes formas de linguagem, de suas misturas, de suas hibridizaçōes, impactando, assim, nas formas de ensinar a língua estrangeira. Não basta promover um ensino tradicional da língua e de seus sistemas de regras gramaticais, fonológicas e sintáticas em uma perspectiva aditiva de aprendizagem proficiente de uma língua após a outra, quando a dinâmica da globalização exige multiplicidade e capacidade de adaptação. As perspectivas multilíngues para o ensino e aprendizagem de línguas têm sido, pois, um campo de investigação aberto no sentido de compreender as dinâmicas transformaçóes tecnológicas, urbanas, locais e globais e procurar compreender o papel da linguagem nas atuais práticas sociais.

\section{Multilingualismo ou Plurilinguismo?}

Em 1990, o renomado historiador Eric Hobsbawn, ao apresentar seu estudo sobre a constituição das nações modernas e o conceito de nacionalismo, defendeu o argumento de que o conceito de Estado-Nação baseia-se em mitos, crenças e ideologias construídas socialmente ao invés de baseadas em antigas tradiçôes. Por isso, explica o autor, a língua, ideologicamente representada em seu papel de atribuir ao Estado e ao seu povo um caráter unitário e de homogeneidade, tem sido, dentre outros, um elemento orgânico na construção do conceito de Estado-nação. Este conceito surge, modernamente, com o declínio da monarquia e ascensão da burguesia e toma corpo em fins do século XVIII e início do XIX. Estadonação - território - povo identificam-se, segundo Hobsbawn, pelo viés da relação língua-cultura, de uma forma mais imaginária do que real. $\mathrm{O}$ objetivo de construir um senso de unidade e de homogeneidade orienta as ações no campo da política de Estado e no campo da política linguística. 
O Brasil colônia e, posteriormente, nação independente, é um exemplo do que analisa Hobsbawn. Severo \& Makoni (2014) relatam que a importância atribuída ao papel exercido pela(s) língua(s) falada(s) no país mudou histórica e ideologicamente, período após período. No Brasil colonial, valorizavam-se as línguas indígenas. A necessidade de tradução dessas línguas levou ao estudo sistemático de seus sistemas e códigos linguísticos resultando na elaboração de gramáticas e dicionários. Para além de uma motivação escolástica e da suposta promoção da diversidade linguística, tais produtos serviam aos interesses da Colônia Portuguesa em sua ação, juntamente com a Igreja, de catequisar os índios e espalhar a língua da Coroa e a sua ideologia católica-cristã, sobrepondo-a à cultura nativa dos indígenas pela integração, fortalecendo, assim o domínio português.

No Brasil pós-colonial, a relação entre língua e identificação nacional tornou-se menos clara e mais conflituosa. Entre a língua portuguesa normativa e sua variação, o português brasileiro, tratava-se de defender qual variedade linguística serviria melhor aos propósitos de identificar a florescente nação brasileira. Este debate acalorou a sociedade intelectual da época e marcou querelas famosas entre escritores, linguistas e filólogos proeminentes.

O Brasil da contemporaneidade procura acomodar todas as variantes. Tem, assegurado em sua Constituição, a língua portuguesa como língua oficial. Assegura a língua pátria como símbolo de identidade nacional e adota, internamente, e de forma progressiva, uma agenda que promove a diversidade linguística, reconhecendo a existência de outras línguas no território nacional como as línguas indígenas, de imigração, dentre outras.

Assim, o percurso do Brasil não difere muito do percurso de outras nações que passaram de Estados coloniais para Estados pós-coloniais (CANAGARAJAH \& LYIANAGE, 2012). Embora a associação entre monolinguismo e nacionalidade seja, teoricamente, uma concepção ultrapassada, considerando as sociedades híbridas e mestiças da contemporaneidade, ainda persiste, para muitos, a crença em uma língua única associada à identidade de um país. Este é um mito cuja aceitação tem origem e é reproduzida nos discursos políticos que pregam a defesa da identidade nacional, mas é também um discurso que ecoa em certas esferas da pesquisa acadêmica no campo da linguagem. Uma mudança de perspectiva para uma abordagem multilíngue precisa, assim, forjar seu caminho, desafiando as crenças majoritárias ligadas essencialmente à noção sistêmica de funcionamento da língua e à noção ideológica de homogeneidade do povo-Estado-nação. 
Por um viés ou por outro, o fato é que questóes linguísticas foram e continuam sendo, cada vez mais, objeto de interesse do Estado e, no cenário do Brasil do século XXI, é preciso ir além da promoção da diversidade linguística como norma inscrita em documentos e buscar meios para a sua implementação em reais condições de constituir-se uma prática corrente e uma política que promova transformações sociais. De uma visão monolíngue, passamos a considerar a opção do multilingualismo como uma ferramenta importante para compreender as relaçôes sociais na contemporaneidade.

O termo 'multilingualismo' vem sendo usado, na pós-modernidade, no contexto das comunicações diversas, superdiversas e multimodais nas quais as línguas estão em contato. Porém, não é um fenômeno novo. Existe desde sempre em que se verificou que línguas estiveram em contato, coexistiram e negociaram sentidos. Apenas chamava-se diferentemente, sendo plurilinguismo o termo usado e adotado por estudiosos nas pesquisas anteriores aos períodos coloniais ou modernos para descrever tais práticas segundo Canagarajah \& Lyianage (2012).

Embora tomados como sinônimos em alguns contextos, no europeu predomina a preferência pelo uso do termo de origem latina. Em vários de seus documentos, a Divisão de Políticas Linguísticas do Conselho da Europa expressa a sua orientação pela adoção de uma política plurilíngue, definindo claramente o conceito de plurilinguismo como valor e como competência, destacando seu papel central na construção do documento de referência e diferenciando-o do conceito de multilingualismo (COUNCIL OF EUROPE, 2007, 2010'). Conforme expresso no Guia para Elaboração de Politicas Linguísticas Educativas na Europa, o plurilinguismo é "A competência potencial e/ou efetiva para usar várias línguas, em graus de competência diversos e para finalidades diferentes". Segundo o documento, os dois conceitos, plurilinguismo e multilingualismo se diferenciam na medida em que o primeiro caracteriza uma "competência dos locutores" para comunicar e interagir por meio da linguagem, ao passo que o segundo representa a "presença das línguas em um dado território" (COUNCIL OF EUROPE, 2007, p. 5). Passamos assim de uma perspectiva centrada nas línguas (um Estado pode ser nominado monolíngue ou multilíngue) para outra centrada nos locutores.

Para Canagarajah \& Lyianage (2012), a diferença atribuída a estes dois conceitos tem uma base tanto teórica quanto ideológica. O plurilinguismo

${ }^{1}$ Disponível em http://www.coe.int/t/dg4/linguistic/Publications_en.asp\#P53_1598 
vê as línguas em interação e postula que a competência em uma língua pode ajudar na compreensão de outras. Em uma comunicação plurilíngue as pessoas podem usar seus repertórios linguísticos próprios, misturando estruturas gramaticais, sintáxicas e/ou léxicas para dar inteligibilidade e eficácia à comunicação - fenômeno que é também conhecido e estudado sobre outras denominações como "codeswitching" ou "codemeshing". Canagarajah (2011), entretanto, distingue os dois conceitos especificando que no primeiro caso, a alternância de línguas em uma comunicação caracteriza uma competência para trocar entre dois (ou mais) sistemas fechados de língua. Atua, portanto, mais no nível lexical da comunicação. $\mathrm{O}$ "codemeshing", por sua vez, compreende as línguas como parte de um único sistema integrado e por isso reconhece a possibilidade de que as trocas aconteçam tanto no nível das diversas competências próprias ao repertório linguístico de cada um, quanto nas modalidades da comunicação. Está, portanto, mais na ordem dos sentidos e do discurso. Em uma perspectiva plurilíngue, tal como a defendida por Canagarajah e Lyianage (2012); Canagarajah (2011), Michael-Luna \& Canagarajah (2007), as línguas são vetores de interação nas práticas discursivas e nos contextos históricos e sociais onde acontece a comunicação.

O multilingualismo², por sua vez, quer no nível societal ou individual, vê as línguas como entidades separadas. A competência em uma língua não interfere na competência em outra. Em seu sentido clássico reproduz uma ideologia da pureza, da homogeneidade e da dominância de uma (ou mais) língua(s) sobre outras. $\mathrm{O}$ termo multilingualismo traz em si a concepção dos ideais da modernidade para os quais a língua, como entidade absoluta, representa a unidade e ideologia do Estado-nação, e se constitui como uma força de colonização.

Segundo Canagarajah \& Lyianage (2012), os dois conceitos constituem formas diferentes de abordar um fenômeno que na prática não apresenta diferença. Talvez o multilingualismo clássico, conforme pontuam os autores, possa carregar em si um valor que pareça menos democrático no uso de diferentes línguas, como se elas fossem coleções independentes que se acumulam no repertório individual de cada um, cada qual assumindo um papel mais importante ou preponderante sobre a outra. É preciso ponderar, por outro lado, se o conceito de plurilinguismo, centrado na competência dos

\footnotetext{
${ }^{2}$ Multilingualismo, termo adotado neste estudo, é usado, por muitos autores, como sinônimo de multilinguismo.
} 
locutores em várias línguas, é, por sua vez, mais igualitário e valorado sempre positivamente quando sabemos que, em muitos contextos de imigração, por exemplo, o pertencimento a comunidades linguísticas consideradas minoritárias tem a questão da língua, e de seu uso, associada a problemas sociais, como baixo rendimento escolar, segregação e preconceito social, além da alegação econômica por parte dos Estados quanto aos altos custos para provimento de uma educação formal na língua de referência do país (BLACKLEDGE \& CREESE, 2010).

A questão posta nestes termos parece levar a uma escolha terminológica dicotômica, em alguns casos mutuamente excludente.. $\mathrm{O}$ fato é que nas sociedades contemporâneas complexificadas, globalizadas, pós-modernas, lidamos com uma multiplicidade de recursos semióticos, dispostos em múltiplas modalidades, e a multiplicidade de línguas não constitui mais a exceção, e sim a regra. Nelas, línguas não são objetos de coleção dos indivíduos, mas um complexo de recursos semióticos específicos - alguns dos quais pertencentes a "linguagens convencionais", outros pertencentes a "outras linguagens" - que colocamos em uso em contextos comunicativos específicos, nas diferentes esferas da vida, inclusive no campo das ideologias sobre a linguagem (BLOMMAERT, 2010, p.102).

Concordando com Heller (2007), é necessário ir além do ideologizado conceito de multilingualismo, como coexistência de sistemas linguísticos fechados, para uma visão crítica dessa coexistência, na qual a linguagem se constitui como prática social situada em contextos sócio-históricos e políticos, usada por atores sociais, sendo delimitada, em suas fronteiras, por limites que são construídos, igualmente, por uma ação social. Portanto, em nenhum momento a linguagem é neutra e isenta de juízos de valor.

A escolha teórica por uma ou outra denominação muda as lentes com as quais se olha o fenômeno, mas não muda o fato de que as práticas de linguagem, codificadas nas diferentes línguas que dominamos ou viabilizadas pelos diferentes recursos semióticos que compõem nosso repertório, são construtos sociais que vão revelar identidades, ideologias, crenças e costumes de sujeitos e de povos-naçôes. Assim sendo, pensando em uma sociedade plural, torna-se importante pensar em práticas plurais de linguagem e uma perspectiva multilíngue abre espaço para que se atribua sentido a estas práticas. Isto deve ser feito criticamente, compreendendo que as línguas não são entidades abstratas, fechadas e homogêneas, mas recursos comunicativos altamente dinâmicos, por meio dos quais agimos no tempo e no espaço histórico, social e político do 
mundo em que vivemos (WEBER \& HORNER, 2013). Isto nos leva a pensar um pouco em como políticas linguísticas refletem práticas sociais próprias ao tempo e ao lugar da contemporaneidade.

\section{Políticas linguísticas no Brasil}

Nos últimos anos, o Brasil, por meio de ações governamentais, tem procurado melhorar sua posição no cenário internacional, investindo em políticas que possam transformar, interna e externamente, sua realidade social, tornando o país mais competitivo e proporcionando oportunidades de crescimento para os seus cidadãos. Dentro do que poderíamos discutir acerca de políticas públicas que promovam bem-estar e ascensão social, interessanos, particularmente, ações no campo das políticas linguísticas, com base no entendimento de que, ao legislar sobre questôes de língua e sobre questôes de linguagem e suas práticas, as ações governamentais interferem e têm consequências na vida dos cidadãos de um país.

Políticas linguísticas e interesses em torno da promoção, ora de uma língua única como símbolo de identidade nacional, ora da diversidade linguística como reconhecimento da necessidade de um olhar plural sobre as múltiplas formas de expressão da linguagem, despertam, de tempos em tempos, o interesse da sociedade. Legislar sobre os usos e as manifestaçōes da ou das línguas que fizeram parte da história e da construção da nação brasileira é uma prática dos governos brasileiros desde os tempos coloniais (SEVERO \& MAKONI, 2014). Na academia, é a partir do século XIX que a diversidade linguística se torna um objeto de estudo consistente, embora circunscrito, no início, a especificidades como, por exemplo, a gramaticalização das línguas (SEVERO \& MAKONI, 2014).

Em geral, o interesse extrapola o âmbito legislativo apenas quando se trata de projetos muito polêmicos ou de iniciativas de grande porte. $\mathrm{O}$ projeto de lei (PL No 1676/1999), proposto pelo então deputado federal, Sr. Aldo Rebelo, para defender a língua portuguesa como patrimônio cultural brasileiro, é um exemplo do primeiro caso. O referido projeto previa a restrição do uso de palavras estrangeiras e, por conseguinte, a obrigatoriedade do uso da língua portuguesa por todos os brasileiros e estrangeiros residentes no país há mais de um ano. Esta restrição seria válida para todo e qualquer uso da língua no âmbito público, no mundo do trabalho, nas relações jurídicas, na mídia, na publicidade de bens e serviços e no ensino e aprendizagem. Inspirado em outro projeto polêmico de mesma natureza, proposto na França 
anos antes, conhecida como Lei Toubon (Lei No 94-665 de 4/08/1994), no Brasil, o projeto gerou reações inflamadas de vários segmentos da sociedade e renovou, na academia, o interesse pelas discussões políticas envolvendo o uso da língua. Linguistas, professores de línguas e estudiosos da linguagem manifestaram-se amplamente sobre o tema, à época (FARACO, 2001; PAIVA \& PAGANO, 2001; RAJAGOPALAN, 2001), não deixando esquecer que políticas linguísticas são o campo de atuação de uma grande área do conhecimento nas ciências humanas, a qual tem, na Linguística Aplicada, a expressão de seu desenvolvimento mais recente.

Entretanto, a junção da esfera acadêmica com a esfera política não aconteceu sempre facilmente. Colocando na conta desvalorizada do senso comum as ações no campo das políticas linguísticas e na prestigiosa conta da ciência os estudos linguísticos, profissionais que teorizam sobre os fenômenos de linguagem, embora se posicionassem, vez por outra, sobre assuntos de política linguística, não consideravam este um assunto dos mais relevantes de suas práticas: "Faz parte da cartilha da nossa disciplina a ideia de que as línguas obedecem às suas próprias leis. Elas evoluem, se renovam, se ajustam a novas exigências de comunicação e de contato com outros povos. Em relação às línguas, portanto, o melhor a fazer deveria ser deixá-las em paz" (RAJAGOPALAN, 2001). Esta dicotomia, entretanto, em nada contribuiu nem para uma melhor compreensão dos fenômenos linguísticos e nem para o desenvolvimento de melhores políticas linguísticas. Sempre houve e sempre haverá intervenções políticas nos usos e nas práticas de linguagem e: "o melhor que podemos fazer [como acadêmicos] é assumir a dimensão política da linguagem para entender e ponderar ações e consequências atuais e futuras" (RAJAGOPALAN, 2001).

Constituído por um mosaico étnico, racial e cultural, o Brasil também é plural no quesito linguístico. Embora a Constituição Brasileira (1988), em seu Art.13, estabeleça a língua portuguesa como idioma oficial, o território nacional acolhe uma grande diversidade linguística. Historicamente, coexistem, no Brasil, além das línguas indígenas, as línguas das comunidades Afro-Brasileiras, as línguas de herança dos imigrantes, a língua brasileira de Sinais, línguas Crioulas e as variaçôes dialetais da própria língua portuguesa (INDL, 2010). O último Censo realizado no Brasil (2010) avança no trabalho de registro da diversidade linguística ao incluir, para os povos indígenas, um quesito de identificação da língua falada, o que permitiu o registro de cerca de 274 línguas indígenas faladas por indivíduos pertencentes a 305 etnias 
diferentes. Conforme se verifica, é, entretanto, recente a atenção dada às línguas indígenas pelas esferas governamentais, com políticas linguísticas públicas específicas para seu reconhecimento e manutenção de sua vitalidade.

As línguas de herança, por sua vez, continuam pouco ou nada consideradas. São caracterizadas como línguas minoritárias por permanecerem vivas, majoritariamente, no seio das comunidades imigrantes. Estudos sobre línguas minoritárias, no Brasil, apontam que a política linguística para as populaçôes de imigrantes "alternou entre momentos de indiferença e de imposição severa de medidas prescritivas e proscritivas" (ALTENHOFEN, 2004, p. 83). Quer pela proibição do uso da língua de herança, quer pela exigência da adoção da língua portuguesa como meio exclusivo de instrução, a língua do imigrante ficou concentrada nos núcleos familiares e societais específicos e foi obrigada a garantir a sua vitalidade pela transmissão oral, de geração a geração, do patrimônio linguístico da família.

No momento da escolaridade, realizada em português, a língua materna (estrangeira) perde força e, em muitas famílias, a manutenção da língua de herança só acontece caso sua aprendizagem seja continuada em instituições privadas de ensino - escolas bilíngues específicas, cursos de idiomas etc. (SAKAMOTO \& MORALES, 2014). Percebe-se, ademais, que o enfraquecimento das línguas minoritárias se dá, também, por fatores externos, próprios à modernidade de nosso tempo. As transformaçôes urbanas, a massificação da cultura pelos meios de comunicação, a emergência de novos códigos e sistemas de linguagem fazem com que outras línguas assumam papel de preponderância.

Neste caso, falta claramente um papel mais ativo das políticas linguísticas de Estado na promoção das línguas minoritárias (línguas estrangeiras de herança). Ao lado da manutenção da língua de herança em família - uma atitude individual que denota uma ação de política linguística - outras instituições (governo, escola, igreja, etc.) deveriam atuar também na promoção da diversidade linguística minoritária.

Em um país com tal diversidade linguística, não se justifica, pois, a manutenção representativa ideológica de uma unidade monolíngue. Um país multilíngue não se constrói apenas pelo reconhecimento da existência de múltiplas línguas, mas pela adoção de medidas institucionais - educacionais, sobretudo - que venham valorizar e manter o patrimônio familiar, linguístico, cultural e histórico de seus cidadãos e que promovam condiçôes de acesso a esse conhecimento. 


\section{Ensinar e aprender línguas estrangeiras}

Uma das formas de promover a diversidade linguística e os direitos linguísticos de uma nação é por meio da educação. No Brasil, nos anos recentes, verificam-se avanços no que se refere ao ensino bilíngue nas comunidades indígenas ${ }^{3}$. Particularmente, o foco deste trabalho recai sobre as línguas estrangeiras que, não sendo objeto de ensino bilíngue, são aprendidas como língua adicional nos mais diversos sistemas de ensino.

O ensino de línguas estrangeiras no Brasil é, em grande medida, dominado por instituições privadas, algumas das quais são associações culturais e educacionais ligadas diretamente aos países estrangeiros das línguas que os representam. Financiadas total ou parcialmente por esses governos, várias associaçôes, como o British Council, para o ensino do inglês, a Alliance Française, para o ensino do francês, o Instituto Cervantes, para a promoção da língua espanhola, o Instituto Goethe, para a língua alemã, e o Instituto Confucius, para o ensino do mandarim, são exemplos de sucesso no mundo todo e não seria diferente no mercado linguístico brasileiro. É neste tipo de instituição, assim como em escolas privadas de idiomas, que o ensino de língua estrangeira cresce a cada dia. Estas instituições agregam valor ao ensino tradicional de línguas por representarem também a cultura das nações que lhes dão origem. Em geral, são associadas a estas instituições os exames de proficiência oficiais ${ }^{4}$ das línguas desses países e muitas delas estabelecem uma estreita parceria com instituições de ensino, sobretudo de nível superior. O sucesso dos cursos de língua estrangeira na iniciativa privada (nesse tipo de instituição ou em escolas de idiomas) verifica-se nos números: quantidade de escolas de línguas espalhadas por todas as cidades brasileiras além da quantidade de alunos que mesmo cursando uma disciplina de língua estrangeira na escola (pública ou privada) frequenta, adicionalmente, um curso privado.

No sistema público educacional, o ensino de língua estrangeira não alcança os mesmos índices de sucesso. Apesar de compor o currículo mínimo do ensino fundamental (a partir do sexto ano), garantida pela Lei de Diretrizes e Bases (LDB) de 1996 que postula a inclusão obrigatória de pelo

3Para uma revisão sobre o tema, ver CAVALCANTI, 1999, 2005.

${ }^{4} \mathrm{O}$ British Council é responsável pela aplicação do exame IELTS; a Alliance Française aplica os testes DELF e DALF; O Instituto Cervantes certifica os Diplomas de Espanhol DELE; e o Instituto Goethe oferece o Goethe-Zertifikat (níveis A1 a C2), além do TestDaf e do Bulats Deutsch-test. 
menos uma língua estrangeira moderna, é de responsabilidade da comunidade escolar, dentro de suas possibilidades, escolher a língua a ensinar (Art. 26, parágrafo 5\%, LDB, 1996). No ensino médio, mantida nos mesmos termos a obrigatoriedade de uma língua estrangeira escolhida pela comunidade escolar, coloca-se ainda a possibilidade de oferta de uma segunda língua estrangeira (em caráter optativo, portanto), desde que, igualmente, dentro das possibilidades da instituição (Art. 36, Inciso III, LDB, 1996).

A vinculação do ensino de língua estrangeira às "possibilidades da instituiçãa”, conforme inscrito na Lei de Diretrizes e Bases, é a justificativa para muitas das deficiências observadas na oferta e na promoção do ensino de línguas estrangeiras no ensino público do país, pois, muitas vezes, por carência destas "possibilidades", este conteúdo é deixado de lado ou ensinado de modo precário. Dadas as deficiências da escola, como, por exemplo, a falta de professor de língua estrangeira, a matéria é atribuída a outro docente. Este problema, verificado no sistema escolar público e relativo a várias disciplinas, não apenas à língua estrangeira, levou o Ministério da Educação a criar o Plano Nacional de Formação de Professores da Educação Básica (PARFOR) que prevê, como uma de suas modalidades, a oferta de uma formação em segunda licenciatura para professores da rede pública que atuem em área distinta da sua formação inicial.

Em vista deste cenário, crenças do senso comum sobre ensino e aprendizagem de línguas estrangeiras se reproduzem e reforçam os ideais de que é impossível aprender língua estrangeira na escola (pública ou privada), que só se aprende língua estrangeira em escolas especializadas (cursos de idiomas, institutos etc.), que o melhor professor de língua estrangeira é o professor nativo na língua de ensino e que, mesmo assim, a melhor alternativa ainda é viajar para o exterior e aprender a língua estrangeira fora do país.

No quesito escolha da língua estrangeira de ensino nas escolas brasileiras, predomina a opção pela língua inglesa. Dada a preponderância do inglês no mundo e o seu reconhecido status de língua franca, esta opção não surpreende, justificando-se, ademais, como necessária. Considerando a situação geográfica do Brasil na América do Sul e Latina, alguns poderiam questionar a legitimidade da opção pelo inglês em detrimento de uma opção pelo espanhol. $\mathrm{O}$ fato é que, somente recentemente, no momento em que a criação de mercados de cooperação como o MERCOSUL ${ }^{5}$ ampliam

${ }^{5}$ O Mercado Comum do Sul (MERCOSUL) é criado em 26 de março de 1991 com a 
oportunidades de intercâmbio entre os países membros, é que a língua espanhola ganhou alguma importância. O reconhecimento nos documentos oficiais ocorreu quando, no ano de 2005, a Lei Federal No $11.161^{6}$ dispôs sobre o ensino da língua espanhola e a incluiu como conteúdo de oferta obrigatória nos currículos plenos do ensino médio - embora de opção facultativa para os alunos - e como conteúdo facultativo nos currículos do ensino fundamental.

Mesmo que o discurso da diversidade linguística venha aos poucos sendo traduzido em medidas institucionais - o que representa um avanço uma política linguística multilíngue requer tempo para ser implementada e exige medidas mais amplas e consistentes do que apenas a promulgação de leis. O sistema educacional (público, privado, em todos os níveis de ensino e, sobretudo, no ensino superior) deve estar preparado para tal e os interesses (de diversas naturezas) no ensino e na aprendizagem de línguas estrangeiras precisam estar claros e bem definidos. O impacto nas escolas, mas também na formação dos professores que terão a responsabilidade de assegurar o ensino destes conteúdos específicos, é de suma importância e as transformações não acontecem instantaneamente.

Afinal, é preciso também se questionar: para que e para quem estamos promovendo o ensino de línguas estrangeiras, no Brasil? Trata-se de uma formação que será acessível para todas as camadas da população brasileira? Ou será mais um conhecimento especializado que, por visar um acesso a uma realidade recente no país - a internacionalização do ensino superior - será possível para poucos?

Como país inserido nos principais contextos internacionais globais participante do G20, do MERCOSUL, do BRICS 7 - tendo sido reconhecido

assinatura do Tratado de Assunção pela Argentina, Brasil, Paraguai e Uruguai. (http:// www.mercosul.gov.br)

${ }^{6}$ https://www.planalto.gov.br/ccivil_03/_Ato2004-2006/2005/Lei/L11161.htm

${ }^{7}$ Brasil, Rússia, Índia, China e África do Sul (BRICS) compõem o grupo de países que se destacaram, nos últimos anos, no cenário mundial, pelo rápido crescimento de suas economias emergentes. Inicialmente um grupo informal, torna-se, em 2006, um mecanismo internacional de caráter diplomático. Em 2010, estimou-se que o PIB (Poder Interno Bruto) dos cinco países corresponderia a 18\% da economia mundial. Estabelecem entre si acordos de cooperação em diversas áreas segundo seus interesses comuns.

Ver: http://www.ipea.gov.br/forumbrics/pt-BR/conheca-os-brics.html 
como a sétima maior economia do mundo em $2014^{8}$, os interesses brasileiros em promover e impulsionar o país mundialmente são uma realidade. Além da atuação no campo político e econômico, avanços no campo da educação, sobretudo no que se refere às altas tecnologias, são necessários para manter o ritmo do crescimento e o papel de proeminência almejado. Essa é a realidade que insere o conhecimento de línguas estrangeiras na agenda do dia, no Brasil, e que agrega também um novo valor à atuação do profissional que trabalha com línguas estrangeiras. Procuraremos mostrar nas seções seguintes de que forma este interesse tem sido traduzido nas práticas reais de ensino e aprendizagem de línguas.

\section{Programa Ciência sem Fronteiras}

Quando associadas a políticas educativas, políticas linguísticas devem ser cuidadosamente pensadas e planejadas. Quer se trate de projetos educacionais nos quais esteja envolvida apenas a língua portuguesa (PEC-G'; Celpe-Bras ${ }^{10}$ ) ou de projetos envolvendo línguas estrangeiras (MARCA ${ }^{11}$, Acordos Bilaterais com agências internacionais, como Campus France ${ }^{12}$, $\mathrm{DAAD}^{13}$, Comissão Fulbright ${ }^{14}$, Programa $\mathrm{IsF}^{15}$ etc.), a cooperação, os acordos e a mobilidade somente acontecem quando são viabilizadas as condiçôes relativas ao conhecimento de língua.

Considerado o projeto governamental de intercâmbio e mobilidade internacional de maior porte já implementado pelo governo federal brasileiro, em 2011, é criado o Programa Ciência sem Fronteiras (CsF).

${ }^{8}$ http://www.valor.com.br/internacional/3532202/estudo-do-banco-mundial-mostrabrasil-como-7

${ }^{9}$ PEC-G - Programa de Estudantes Convênio de Graduação

${ }^{10}$ Celpe-Bras - Certificado de Proficiência em Língua Portuguesa para Estrangeiros

${ }^{11}$ MARCA - Programa de Mobilidade Acadêmica Regional em Cursos Acreditados (MERCOSUL)

${ }^{12}$ Campus France - Intercâmbio Brasil - França

${ }^{13} \mathrm{DAAD}$ - Serviço Alemão de Intercâmbio Acadêmico

${ }^{14}$ Comissão Fulbright - Intercâmbio Brasil - Estados Unidos

${ }^{15} \mathrm{IsF}$ - Idiomas sem Fronteiras 
Coordenado pelas agências de fomento $\mathrm{CNPq}^{16} \mathrm{e}^{\mathrm{CAPES}}{ }^{17} \mathrm{com}$ a chancela dos Ministérios da Ciência, Tecnologia e Inovação (MCTI) e da Educação (MEC), o programa objetiva "promover a consolidação, expansão e internacionalização da ciência e tecnologia, da inovação e da competitividade brasileira”. Incialmente sua meta consistia na implementação de até 101 mil bolsas de estudo para estudantes e pesquisadores brasileiros em nível de graduação e de pós-graduação, para intercâmbio e mobilidade científica em universidades de excelência, no exterior, em áreas prioritárias para o desenvolvimento da ciência e da tecnologia no país. Previsto para durar apenas quatro anos, o programa foi reeditado (anúncio feito em 25 de junho de 2014 pela Presidente da República ${ }^{18}$. Nesta segunda edição, está prevista, como meta, a concessão de um adicional de mais 100 mil bolsas de estudo. Ainda segundo declaração da Presidente da República, no ato do lançamento da segunda fase do programa, ao manter o foco nas ciências técnicas ${ }^{19}$, o programa segue com o objetivo de ajudar o país a se desenvolver tecnologicamente: "Esse é um programa feito para garantir ao Brasil condiçōes de gerar aqui inovação, aumentar o interesse pelas ciências exatas e a aplicação de tecnologia em todas as áreas"20.

Incentivos públicos em nível de Mestrado, Doutorado Pleno e Doutorado Sanduíche, sob a forma de bolsas de estudos CAPES e CNPq, já acontecem normalmente há algumas décadas, no Brasil. No entanto, o programa CsF representa a primeira grande iniciativa voltada para a mobilidade internacional envolvendo estudantes de graduação, nos moldes do que já acontece há vários anos em outros países. Um exemplo consolidado pode ser observado nos países membros da Comunidade Europeia, com os programas Erasmus, Erasmus Mundus e a sua mais recente versão, o programa Erasmus+. Implantado

\footnotetext{
${ }^{16} \mathrm{CNPq}$ - Conselho Nacional de Desenvolvimento Científico e Tecnológico ${ }^{17}$ CAPES - Coordenação de Aperfeiçoamento de Pessoal de Nível Superior ${ }^{18} \mathrm{http} / /$ g1.globo.com/educacao/noticia/2014/06/dilma-anuncia-100-mil-bolsas-para2-etapa-do-ciencia-sem-fronteiras.html

${ }^{19} \mathrm{O}$ Programa CsF contempla 18 grandes áreas relativas à ciência, tecnologia e inovação. Para uma lista completa ver http://www.cienciasemfronteiras.gov.br/web/csf/areas-contempladas. ${ }^{20}$ Exma. Sra. Dilma Roussef, Jornal O Globo. http://g1.globo.com/educacao/ noticia/2014/06/dilma-anuncia-100-mil-bolsas-para-2-etapa-do-ciencia-semfronteiras.html
} 
em 2014, esta última versão do programa ${ }^{21}$ tem por objetivo impulsionar o desenvolvimento de habilidades específicas e aumentar a empregabilidade de mais de 4 milhões de cidadãos europeus, investindo na educação em geral, no treinamento e educação de jovens e no desenvolvimento do esporte. A inclusão do esporte no âmbito de um programa deste alcance, além da ampliação da faixa etária contemplada para os mais jovens, denota a visão de educação integral que caracteriza a política de mobilidade e internacionalização dos países envolvidos.

No Brasil, embora pioneiro e muito bem recebido pelos diversos setores da sociedade, o Programa CsF não passou sem críticas. A primeira delas, desde a sua criação, diz respeito à exclusividade das áreas contempladas deixando de fora a grande área das Ciências Humanas e Sociais. A segunda diz respeito ao nível de conhecimento de língua estrangeira exigido para a participação no programa.

No que diz respeito à primeira grande crítica, as reações geraram muitas matérias jornalísticas e debates no âmbito das instituições de ensino. A questão de fundo, neste caso, diz respeito ao conceito de "Ciência". Promover o avanço da ciência no país não deveria passar apenas pelos incentivos nas áreas das ciências exatas e naturais, pois uma educação integral não pode prescindir de valores humanísticos. $\mathrm{O}$ avanço das ciências exatas e naturais não acontece sem ética, sem uma compreensão integral do indivíduo, de suas relaçóes e da realidade social na qual se insere. Assim, privilegiam-se determinadas áreas em detrimento de outras que também contribuem para a construção do profissional que, posteriormente, poderá, por meio da formação adquirida, fazer avançar a ciência, a tecnologia e inovar para o país.

Com a defesa geral de que as áreas carentes de investimento na formação de profissionais competitivos no mundo globalizado são, prioritariamente, as á reas das ciências exatas, biológicas e tecnológicas, o governo brasileiro manteve seu critério, o qual continua na segunda edição do programa. Talvez como forma de responder às críticas recebidas, dois projetos foram divulgados recentemente, contemplando setores específicos das áreas não contempladas. São eles o programa Culturas sem Fronteiras, do Ministério da Cultura, e o Projeto de Qualificação Internacional, do Ministério do Turismo, ambos lançados no primeiro semestre de 2014. Entretanto, o alcance e dimensão dos dois projetos são muito inferiores aos do programa $\mathrm{CsF}$, sobretudo no que se refere aos valores dos investimentos, ao número de países envolvidos e ao número de participantes.

A segunda grande crítica diz respeito ao conhecimento de língua estrangeira exigido dos participantes. Um programa de mobilidade

${ }^{21} \mathrm{http}: / /$ ec.europa.eu/programmes/erasmus-plus/discover/index_en.htm 
internacional, como seu nome já anuncia, pressupõe a necessidade de competências específicas para transitar no âmbito de comunidades internacionais e a proficiência em língua estrangeira é uma condição necessária para que isto se concretize. Desde seu lançamento, esta se revelou uma fragilidade do programa. Muito cedo, ficou claro para os gestores do programa, e para a sociedade em geral que, sem conhecimento de língua estrangeira - sobretudo da língua inglesa - o programa não teria sucesso.

Em decorrência desta realidade inicial, os números do programa apontaram, nas primeiras chamadas, a escolha por Portugal como um dos países de destino mais procurados pelos alunos em nível de graduação. Dados fornecidos pela Capes e pelo CNPq para a Agência Brasil de notícias e publicados na mídia, em geral, em setembro de 2012, ou seja, um ano após o lançamento do programa destacam que um em cada cinco alunos do Programa escolheram uma instituição lusitana ${ }^{22}$. Além disso, o baixo número de candidatos aprovados para outros destinos evidenciava o fraco desempenho em língua estrangeira. Nas chamadas para o Reino Unido, correspondentes ao ano letivo 2012-2013, das 4 mil bolsas oferecidas pelo CsF, apenas 1,8 mil foram preenchidas por falta de candidatos com proficiência satisfatória em língua inglesa. A alta taxa de reprovação levou os gestores do programa no Brasil e no Reino Unido a reduzir a pontuação mínima exigida nos exames de certificação, além de promover cursos intensivos de inglês antes do início das atividades específicas do curso escolhido, nas universidades britânicas ${ }^{23}$.

Reagindo a tais fatos, uma das primeiras medidas tomadas no Brasil, pelos Ministérios envolvidos e pelas agências de controle do programa para fazer face à dificuldade linguística, foi a criação de um Plano de Ação voltado para o ensino de inglês. Intitulado Inglês sem Fronteiras, este programa adicional tem por meta proporcionar oportunidades de acesso a estudantes das Instituiçôes de Ensino Superior candidatos a programas de mobilidade internacional como o CsF, incentivando o aprendizado e o aprimoramento da língua estrangeira. Incialmente estruturado na forma de um curso de línguas à distância (online), o estudante poderia estudar inglês e se preparar para os exames de proficiência exigidos pelas instituições estrangeiras.

\footnotetext{
${ }^{22}$ http://ultimosegundo.ig.com.br/educacao/2012-12-03/universidade-de-coimbra-eo-principal-destino-do-ciencia-sem-fronteiras.html

${ }^{23}$ http://ultimosegundo.ig.com.br/educacao/2013-02-07/apos-reprovacao-alta-nivelde-ingles-exigido-para-bolsas-sera-menor.html
} 
Atualmente, o Inglês sem Fronteiras foi abarcado por um programa de maior abrangência, o Idiomas sem Fronteiras (IsF). Com um escopo maior, suas ações incluem a aplicação de testes de proficiência, cursos à distância e presenciais de línguas nas universidades cadastradas. Seu objetivo é de que possa promover essa gama de açôes não somente para a língua inglesa, mas para um total de sete línguas estrangeira $\mathrm{s}^{24}$. Um primeiro passo nesse sentido foi dado em novembro de 2014 com o lançamento do Francês sem Fronteiras ${ }^{25}$ com os mesmos objetivos e metas.

Como já ressaltado anteriormente, estas foram iniciativas que vieram a reboque do programa maior CsF. Reagem à constatação de que havia uma deficiência no conhecimento de língua estrangeira de parte dos candidatos à mobilidade internacional. Iniciativas como estas certamente melhoraram os índices de aprovação dos candidatos e os números do programa cresceram. Segundo os indicadores do $\mathrm{CsF}^{26}$, os países de língua inglesa (Estados Unidos, Reino Unido e Canadá) correspondem aos destinos mais procurados pelos bolsistas, seguidos da França e da Alemanha.

Porém, desde a criação do CsF, em 2011, além das ações relativas ao incentivo para a aprendizagem e o aperfeiçoamento do conhecimento de língua estrangeira, outras medidas para aumentar a possibilidade de participação dos estudantes brasileiros no programa foram sendo tomadas, nem todas isentas de críticas. Como, em muitos casos, o conhecimento de língua estrangeira encontrava-se abaixo do esperado e do exigido pelos critérios de seleção dos países e das instituições: 1) a exigência no nível de conhecimento de língua estrangeira foi diminuída ${ }^{27}$; e 2) foi implantada a possibilidade de custear um estágio linguístico (variando de um a seis meses

\footnotetext{
${ }^{24}$ Informação obtida por comunicação pessoal com a Profa Denise Martins de Abreu e Lima, coordenadora geral do programa IsF, durante bate-papo online (hangout) promovido pela Rede CsF em 16 de novembro de 2014.

(Ver: https://www.youtube.com/watch?v=X7Jz195wyg0 )

${ }^{25} \mathrm{http}: / /$ isf.mec.gov.br/frances/pt-br/o-programa

${ }^{26} \mathrm{~A}$ divulgação dos números do programa está a disposição na página oficial do CsF, Portal CAPES, e é atualizada periodicamente. Ver: http://www.cienciasemfronteiras. gov.br/web/csf/painel-de-controle

${ }^{27}$ Ver notícia divulgada sobre redução da pontuação mínima exigida nos exames de certificação para alunos concorrendo a bolsas no Reino Unido em http://ultimosegundo. ig.com.br/educacao/2013-02-07/apos-reprovacao-alta-nivel-de-ingles-exigido-parabolsas-sera-menor.html
} 
a depender do país e da instituição) no país de destino para o aluno menos proficiente, antes do início do curso propriamente dito ${ }^{28}$.

Especialistas na área da educação e do ensino de línguas se pronunciaram, sobretudo na mídia, quanto à adoção das duas medidas, explicando que, no primeiro caso, a redução do nível exigido traria prejuízos tanto para o programa quanto para os alunos, significando, em alguns casos, enviar para o exterior alunos que mal teriam condições de manter uma conversação básica. As dificuldades de compreensão mútua e o aproveitamento dos estudos estariam seriamente comprometidos.

Quanto à segunda medida, ou seja, a adição de um tempo maior para frequentar um curso de idiomas em imersão, no país e instituição escolhidos, as reaçōes variaram. Há um entendimento geral de que cursos intensivos de línguas, sobretudo em imersão, são, uma medida eficiente para aperfeiçoar o domínio da língua estrangeira e isto vale para qualquer pessoa em qualquer situação. Mesmo que em graus variados, sempre se tem benefícios. Entretanto, a falta de controle sobre a natureza e conteúdos do curso, bem como sobre a sua duração (sendo estas decisões uma prerrogativa das instituições no exterior e, portanto, variando caso a caso) deixaram os especialistas em dúvida quanto ao efetivo benefício desta segunda medida. Isto sem contar as críticas que apontavam, nestes casos, para o aumento do custo do aluno beneficiado por aumentar seu tempo de permanência no exterior.

É fato que qualquer oportunidade de aprendizado adicional traz benefícios para quem dela aproveita. Porém, o que se questiona é que, dados os objetivos do programa, a proficiência em língua estrangeira, que é um meio de instrução e não o seu objetivo final, deveria ser um pressuposto. E, sendo assim, o aprendizado de língua estrangeira deveria acontecer no Brasil antes da ida para o exterior, mesmo que ele fosse aperfeiçoado lá, o que muda a configuração do problema. Este aperfeiçoamento poderia acontecer tanto pela oportunidade do curso de línguas em imersão, e deveria ser um benefício concedido para todos, ou acontecer naturalmente ao longo da experiência do ano passado em contato com os falantes nativos da língua do país estrangeiro, o que, com um mínimo de esforço de interação, acontece para todos. O fato

\footnotetext{
${ }^{28}$ A duração da bolsa concedida pelo programa CsF é de 12 meses, podendo estender-se até 18 meses quando incluir curso de idiomas. O prazo para o curso é apresentado na Chamada, variando segundo o país e o acordo firmado com a universidade no exterior. Ver: http://www.cienciasemfronteiras.gov.br/web/csf/graduacao
} 
do aluno menos proficiente ter a oportunidade de realizar um curso prévio de língua no país de destino antes de iniciar suas atividades específicas certamente ajuda, mas não garante, por si só, que ele supere a sua carência linguística.

É, pois, fundamental avaliar os objetivos pretendidos com um programa de amplo alcance e alto impacto como o CsF. Não se trata de basear as ambições linguísticas para o aluno participante em um modelo de proficiência correspondente à competência de um falante nativo da língua estrangeira, o que nos faria perpetuar conceitos arraigados, ainda, em muitos cursos de formação de professores de línguas e compartilhados por muitos aprendizes de línguas de que o referencial é o falante nativo - ainda que se questione o que é o falante nativo. Em uma perspectiva multilíngue da sociedade contemporânea, esta ambição é altamente desaconselhada. Por outro lado, também não se pode pensar em enviar estudantes para universidades de excelência no mundo todo (conforme meta do programa), para que possam se beneficiar dos ambientes de aprendizado e de pesquisa de ponta dessas instituições, sem que eles compreendam o que estão fazendo por ter dificuldades básicas de compreensão da língua. Nem o estudante alcançará seus objetivos de aprendizagem, nem o governo brasileiro alcançará os objetivos de fomentar a pesquisa científica e a inovação no país, com o retorno de estudantes mais bem preparados e qualificados.

Em suma, partimos do pressuposto de que o programa CsF é uma iniciativa bem-vinda e uma ação de sucesso pelas transformações já observadas na realidade das universidades brasileiras, nos números oficiais apresentados pelos órgãos de controle e no depoimento dos jovens participantes ${ }^{29}$. Não obstante, é preciso avaliar tanto os indicadores de sucesso quanto as fragilidades - pois as críticas existem - e, neste caso, procurar agir para superá-las. Estas ações devem ir além das ações emergenciais, necessárias no contexto, as quais, para que sejam benéficas a médio e longo prazo, devem se transmutar em políticas linguísticas e em políticas de ensino que promovam o efetivo e desejado avanço da ciência e da tecnologia, da melhoria da educação superior e do progresso da sociedade, em geral. Muitas das críticas dos setores competentes envolvidos no processo: instituiçóes de ensino e empresas patrocinadoras do programa que contribuem financeiramente

\footnotetext{
${ }^{29}$ Parte dos dados coletados na pesquisa que embasa este texto constitui-se de depoimentos de alunos participantes do CsF. Entretanto, estes dados serão objeto de tratamento em publicaçôes posteriores.
} 
com um percentual das bolsas de estudo do programa CsF, por exemplo, mas igualmente da sociedade em geral, vêm da certeza da necessidade de uma avaliação constante das ações e dos indicadores apresentados para que os números de sucesso ou insucesso sejam comprovados.

Uma tentativa de contribuir para este debate e apresentar uma avaliação do panorama linguístico de participantes do programa CsF será apresentada na seção a seguir com alguns dados da pesquisa.

\section{A pesquisa}

O programa Ciência sem Fronteiras transformou, no Brasil, a realidade das universidades brasileiras e a vida de seus jovens participantes. Isto pode ser comprovado pelos números apresentados pelas instituições, pelo incremento nas ações de internacionalização, pelos números apresentados pelo governo, pelos dados das agências de fomento que coordenam o programa (CAPES e $\mathrm{CNPq}$ ), além dos depoimentos de alunos espalhados Brasil e mundo afora. Todos estes dados podem ser lidos nos documentos oficiais, governamentais e das instituiçôes de ensino; nas inúmeras matérias divulgadas em todo tipo de mídia; e, também, nas redes sociais, sobretudo no que se refere ao ponto de vista dos estudantes. $\mathrm{Na}$ academia, em diversas áreas do conhecimento, o fluxo de pesquisas tendo como objeto, direto ou indireto, o programa CsF é crescente.

Como apoio ao argumento defendido neste artigo, de que o Brasil se beneficiaria ao assumir uma perspectiva multilíngue e ao adotar políticas linguísticas que promovessem condições de ensino e aprendizagem de línguas consoantes com as necessidades da sociedade contemporânea globalizada, vamos apresentar, a seguir, dados parciais da pesquisa em andamento que investiga as competências linguísticas de estudantes de graduação brasileiros, bolsistas do programa CsF. Esta pesquisa, cujo escopo total não será apresentado neste trabalho, tem por objetivo geral a construção do perfil linguístico dos participantes, além de uma avaliação da experiência de mobilidade e do programa. Dos dados coletados até o momento (por meio de um questionário online organizado em seis sessóes: identificação do participante; avaliação das competências linguísticas; avaliação da experiência pessoal; avaliação da universidade, curso e programa de estudos no exterior; avaliação do programa CsF; perguntas abertas, caracterizando um amplo material quantitativo e qualitativo) destacaremos apenas duas questôes: 1) Em que contexto foi aprendida a língua estrangeira do país (ou a língua de instrução do curso/universidade) onde o participante realiza o CsF; e 2) Qual 
o tempo de estudo dedicado a este aprendizado. As respostas apresentadas correspondem a uma amostra parcial de 99 participantes ${ }^{30}$.

As tabelas 1 e 2 apresentam a distribuição de respostas relativas ao contexto de aprendizagem da língua estrangeira alvo para a participação do bolsista no programa CsF. A primeira tabela apresenta as opções de resposta apresentadas ao participante no instrumento de pesquisa. Os números de ocorrência referem-se aos participantes que escolheram apenas uma opção de resposta e por isso estão sendo chamadas de respostas simples.

TABELA 1

\begin{tabular}{lc}
\hline Contexto de aprendizagem da língua estrangeira (respostas simples) \\
\hline Escola regular pública & - \\
Escola regular privada & 02 \\
Curso de línguas no Brasil & 28 \\
Curso de línguas no exterior & 01 \\
Professor particular & 02 \\
Pela internet & - \\
Sozinho & 02 \\
Morando no exterior & 03 \\
Outro: Família & 02 \\
Outro: Na faculdade & 01 \\
\hline TOTAL & 41 \\
\hline
\end{tabular}

Fonte: Banco de dados (questionário online) da pesquisa realizada pela autora com alunos do Programa CsF em 2014.

A segunda tabela apresenta os números relativos aos participantes que marcaram mais de uma opção de resposta, uma vez que lhes era facultado essa possibilidade, caso ele se enquadrasse em mais de um caso. Estas respostas estão sendo chamadas de respostas compostas. Neste caso, as respostas foram agrupadas considerando sempre a primeira opção escolhida.

\footnotetext{
${ }^{30}$ Este era o número de participantes tendo respondido ao instrumento de pesquisa no momento da redação deste artigo. A divulgação da pesquisa para ampliação do número de participantes conta com a colaboração da Rede CsF, associação não governamental, sem fins lucrativos, criada por estudantes participantes de Mobilidade Acadêmica Internacional para troca de experiências, conhecimentos e oportunidades ( http://www.redecsf.org ).
} 
TABELA 2

\begin{tabular}{lc}
\hline Contexto de aprendizagem da língua estrangeira (respostas compostas) & 01 \\
\hline Escola regular pública, sozinho e pela internet & 38 \\
Escola regular privada e outras modalidades & 16 \\
Curso de línguas no Brasil e outras modalidades & 01 \\
Curso de línguas no exterior e morando no exterior & 02 \\
\hline Professor particular e sozinho pela internet & 58 \\
\hline TOTAL
\end{tabular}

Fonte: Banco de dados (questionário online) da pesquisa realizada pela autora com alunos do Programa CsF em 2014.

A maior incidência de respostas simples recai sobre o aprendizado de línguas realizado em curso de línguas/idiomas no Brasil. Nas respostas compostas, a maioria das ocorrências recai sobre a aprendizagem realizada em contextos mistos, nos quais a referência é inicialmente a escola privada (em geral o ensino fundamental e médio) associada a outras modalidades como o uso da internet, a contratação de professor particular, cursos no exterior, além dos próprios cursos pré-estágio oferecidos pelo CsF, na universidade no exterior e da experiência adquirida pelo contato diário com a língua no país estrangeiro.

Conjugando os dados das duas tabelas, percebe-se que os cursos de línguas, como contexto único de instrução ou associado a outras modalidades, são, ainda, a primeira referência quando se trata de aprender língua estrangeira, no Brasil, totalizando $44,4 \%$ dos casos analisados.

Consideremos, a seguir, o dado complementar relativo ao tempo de estudo dedicado ao aprendizado da língua estrangeira. Esta era uma pergunta que incluía um espaço adicional de resposta aberta e, portanto, o respondente tinha a possibilidade de detalhar e explicar o que ele julgasse ser necessário em relação ao conteúdo perguntado.

TABELA 3

\begin{tabular}{lc}
\hline Tempo de estudo da língua estrangeira & \\
\hline Até um ano de estudo & 17 \\
Entre um e dois anos de estudo & 05 \\
Entre dois e cinco anos de estudo & 28 \\
Entre cinco e dez anos de estudo & 24 \\
Entre dez e quinze anos de estudo & 07 \\
Desde a infância (acima de quinze anos de estudo) & 16 \\
\hline
\end{tabular}

Fonte: Banco de dados (questionário online) da pesquisa realizada pela autora com alunos do Programa CsF em 2014. 
É interessante observar que a grande maioria dos participantes estudou língua estrangeira por longos anos. Menos de 20\% dos respondentes declara ter se dedicado a esta matéria em um período menor do que um ano. Ou seja, o investimento no aprendizado de língua estrangeira leva tempo. Associando os dois dados, contexto e tempo de estudo, não se observa um padrão que associe um determinado contexto de estudo a um tempo de estudo específico. Excetuando aqueles que sempre tiveram contato com a língua estrangeira em contexto familiar bilíngue, a maioria dos participantes passou por algum contexto formal (escola ou curso de idiomas) de ensino. No que se refere às modalidades de estudo associadas ao contexto formal de aprendizagem, destacam-se como de maior incidência a internet e a dedicação individual (sozinho) ao estudo da língua estrangeira.

Ampliando o escopo e analisando estas informações no contexto do desenvolvimento de políticas linguísticas para o ensino e aprendizagem de línguas estrangeiras no Brasil, verificamos que os dados reforçam a prevalência do ensino particular e privado para o aprendizado de línguas estrangeiras. Até o momento, por falta de um estudo específico, não há como avaliar o impacto da formação em língua estrangeira oferecida pelos programas adicionais de ensino que compõem, por exemplo, o Idiomas sem Fronteiras. É importante citar que, no momento da coleta de dados da pesquisa, o único programa implantado era o Inglês sem Fronteiras. Pesquisas futuras específicas sobre o impacto destes programas poderão contribuir para novas compreensões.

Os dados apontam ainda para o fato de que aprender língua estrangeira no Brasil é um investimento custoso tanto no sentido financeiro quanto temporal. E não se observa que as leis de obrigatoriedade de ensino de línguas no ensino médio tenham transformado esta realidade. Depoimentos dos alunos do programa $\mathrm{CsF}$ continuam a explicitar que é no exterior que eles conseguem alavancar suas competências linguísticas. O depoimento que segue é bastante representativo:

"Estudo inglês desde a $3^{\text {a }}$ serie, ou seja, desde quando tinha 9 anos. Somente agora, durante o intercâmbio acadêmico, foi que me senti confiante o bastante para dizer que domino a língua. Então, respondendo a questão, 13 anos" (participante da pesquisa).

O participante relata que, apesar dos 13 anos de dedicação ao estudo de língua estrangeira, somente pela vivência da experiência de mobilidade 
é que ele pode assimilar este conhecimento. É forte, ainda, a crença de que uma língua estrangeira só será realmente aprendida se for pelo contato com falantes nativos do idioma (quer via professores ou via imersão no exterior). Porém, sem um investimento prévio, de estudo e de tempo, até essa alternativa pode não resultar no objetivo desejado. Assim, conforme os dados, a melhor estratégia para viabilizar o aprendizado de línguas parece ser aquela que oferece as maiores e mais diversas oportunidades. Não somente nos contextos formais de ensino (escolas, universidades, cursos de idiomas), mas igualmente as estratégias de aprendizagem informais (internet, jogos, redes sociais, etc.), tão diversas, interativas e naturais nas sociedades contemporâneas. A pergunta que se coloca, face a este dados, é se estas oportunidades estão acessíveis para todos.

\section{Conclusão}

Perguntamos anteriormente, para que e para quem serve a promoção do ensino de línguas estrangeiras, no Brasil. Embora os elementos de resposta a esta indagação não sejam simples nem definitivos, podemos elencar dois pontos para uma reflexão sobre o tema.

1) $\mathrm{O}$ aprendizado de uma ou mais língua(s) estrangeira(s) é, na contemporaneidade, uma resposta ao modelo de sociedade globalizada que se impõe. O desenvolvimento nas comunicações, o compartilhamento de informações e as mobilidades transnacionais exigem esse conhecimento. $\mathrm{O}$ ensino e o profissional que atua neste mercado ganham renovada importância e o que ensinar e como ensinar também voltam a ter destaque nas agendas de pesquisa. As línguas lutam por manter ou retomar seus espaços de proeminência global, enquanto prevalecem a soberania e a abrangência da língua inglesa como língua franca, por excelência. Discussões conceituais sobre plurilinguismo ou multilingualismo definem a diferença na abordagem adotada para lidar com as questôes de linguagem, mas convergem para a necessidade de uma prática plural. A globalização viabiliza e naturaliza a diversidade e a multiplicidade, mas exige, em troca, capacidade de adaptação.

Procuramos demonstrar, pela análise da trajetória do CsF e das medidas adicionais que foram sendo tomadas em decorrência das primeiras dificuldades relativas ao desempenho linguístico dos candidatos à mobilidade internacional, a importância que tem a língua para a eficácia de um programa governamental que tem buscado introduzir mudanças ao ensino superior no país. Tais medidas são, em resumo, a criação do programa Inglês sem 
Fronteiras com cursos à distância; a diminuição da pontuação mínima em testes de proficiência; a aplicação gratuita de testes de proficiência nas universidades; os cursos de línguas nas universidades no exterior, a ampliação do programa de formação de línguas estrangeiras para outros idiomas, os cursos adicionais presenciais de línguas estrangeiras nas universidades cadastradas e o intercâmbio de professores estrangeiros e brasileiros para impulsionar a formação profissional. Estas medidas (nem todas tratadas no âmbito deste artigo por extrapolar a discussão proposta) respondem aos interesses de um projeto de governo e a um modelo de sociedade que atua em rede, em cooperação, em intercâmbio, em mobilidade. Mesmo considerando que essa cooperação e intercâmbio não trazem implícitos em si relações de igualdade, é na busca de melhores condiçōes para estabelecer esses parâmetros e se posicionar no mundo globalizado que os projetos são desenvolvidos.

2) $O$ aprendizado de línguas estrangeiras no Brasil ainda atende a uma população que pode se permitir o acesso a essa formação. Os dados de pesquisa sobre as competências linguísticas dos estudantes de graduação participantes do programa CsF, parcialmente apresentados neste trabalho, apontam para o domínio do ensino privado e pago no cenário do ensino de línguas, no Brasil. Apenas o tempo de estudo durante a escolaridade formal pública ou privada - não parece garantir o aprendizado de língua estrangeira. Isto, por si só, já é um indício de que as políticas públicas concernentes às questôes de linguagem e seu uso, sobretudo nos contextos institucionais de ensino, pelo descompasso entre proposta e implementação, têm sido pouco eficazes. Por outro lado, uma oferta monolíngue não acompanha as possibilidades viabilizadas pelo acesso à mobilidade internacional, facilitada, nos tempos atuais e de forma inédita, por programas educacionais institucionais (como o CsF e outros), mas facilitados, igualmente, pela multiplicidade de oportunidades de deslocamento e relocação de sujeitos ao redor do mundo, levados pelas mais diversas motivaçôes pessoais - o que sempre foi uma alternativa para aqueles que podiam se permitir pagar por isso. Com exceções, é o indivíduo com melhores condições sociais e financeiras que tem acesso a uma formação multilíngue e que pode, portanto, se beneficiar destas oportunidades.

Assim, parece que o ensino de língua estrangeira, por mais proeminente e relevante que seja para a sociedade contemporânea e para o Brasil, ainda precisa ser melhor planejado para ser melhor executado, mesmo com um potente carro-chefe como o programa $\mathrm{CsF}$ que tem beneficiado milhares de jovens universitários em todo país. 
Discutimos neste trabalho a natureza e a pertinência das políticas linguísticas adotadas no Brasil face à globalização que instala um novo modo de estar e de viver no mundo. Discutimos, igualmente, ações educacionais para as quais a transversalidade do ensino e aprendizagem de línguas estrangeiras tem uma relevância constitutiva. No Brasil, motivados pela nova realidade fomentada pelo programa de mobilidade internacional CsF, o campo do ensino e da aprendizagem de línguas estrangeiras necessita ser repensado para acompanhar o ritmo acelerado desta e de outras açóes inovadoras, que têm transformado a educação no país, especialmente a educação superior. Desta forma, no que se refere especificamente ao ensino e à aprendizagem de línguas estrangeiras, é preciso problematizar e propor novas estratégias para transformar e avançar. Políticas públicas, linguísticas e educacionais, são essenciais para este planejamento e precisam ser consubstanciadas por reflexões e avaliaçóes constantes.

Os desafios à frente nos levam, portanto, a defender, cada vez mais, políticas públicas inclusivas. É claro que no campo político, um planejamento não se efetiva sem recursos e sem o enfrentamento de condições de implementação. Não basta legislar sobre o que deve ser ensinado e em que nível. São necessários professores, e estes precisam de formação especializada. É preciso intercâmbio de conhecimento não apenas nas áreas elitizadas do conhecimento científico, mas igualmente naquelas que promovem a base para que este tipo de ciência se desenvolva. Políticas públicas e políticas linguísticas mais inclusivas representariam, assim, uma mudança de valores e de prioridades. Programas como o CsF criam esta necessidade e nos levam a reagir para acompanhar sua velocidade e expansão. A globalização é um fato e o domínio de uma ou mais línguas estrangeiras é uma competência necessária. Dadas as ambições do país, é hora do Brasil avaliar suas próprias políticas e prover condiçōes para que as transformaçōes aconteçam sobre bases planejadas e não sobre alicerces adicionados ao sabor dos acontecimentos.

\section{Agradecimentos}

Agradeço aos avaliadores da RBLA pelas sugestões e a CAPES pelo apoio financeiro à pesquisa (Processo BEX 10931/13-9, 2014) durante estágio Pós-doutoral no Birkbeck College, University of London, UK. Agradeço ainda ao Professor Jean-Marc Dewaele pelo apoio e interlocução durante a realização da pesquisa no exterior. 


\section{Referências}

BAKHTIN, M. Formas do tempo e de cronotopo no romance. Ensaios de poética histórica. In: BAKHTIN, M. Questôes de literatura e de estética. 2a ed. São Paulo: Hucitec, . p. 211-362, 1990

BAUMAN, Z. Modernidade líquida. Rio de Janeiro: Zahar, 2001.

BAUMAN, Z. Globalização: as consequências humanas. Rio de Janeiro: Zahar, 1999.

BEACCO, J.C. Migrations et Éducation Plurilingue. In: EXTRAMIANA, C. \& SIBILLE, J. Migrations et Plurilinguisme en France. Cahiers de l'Observatoire des pratiques linguistiques,. n. 2. Paris: Éditions Didier, 2008.

BEACCO, J.C. \& BYRAM, M. Council of Europe. Guide for the development of Language Education Policies in Europe (final version). 2007. Disponível em: <http:// www.coe.int/t/dg4/linguistic/Publications_en.asp\#P53_1598.> Acesso em: 10 set. 2014. BEACCO, J.C.; BYRAM, M.; CAVALLI, M.; COSTE, D.; CUENAT, M.E.; GOULLIER, F. \& PANTHIER, J. Council of Europe. Guide for the development and implementation of curricula for plurilingual and intercultural education. 2010. Disponível em: <http://www.coe.int/t/dg4/linguistic/Publications_en.asp\#P53_1598>. Acesso em: 10 set. 2014.

BLACKLEDGE, A. \& CREESE, A. Multilingualism. A critical perspective. London: Continuum, 2010.

BLOMMAERT, J. The Sociolinguistics of Globalization. Cambridge: Cambridge University Press, 2010.

BLOMMAERT, J.; BACKUS, A. Repertoires revisited: 'knowing language' in superdiversity. Working Papers in Urban Language and Literacies. Paper 67. London: Tilburg University and King's College, 2011. Disponível em: <www.kcl.ac.uk/ldc> . Acesso em: 23 mar. 2013.

BLOMMAERT, J.; RAMPTON, B. Language and Superdiversity. Diversities, v. 13, n. 2, p. 2079-6595, 2011. Disponível em: <www.unesco.org/shs/diversities/vol13/ issue2/art1 (C) UNESCO>. Acesso em: 23 mar. 2013.

BOURDIEU, P. Language and Symbolic Power. Cambridge: Polity Press, 1991.

BRASIL. Ministério da Ciência, Tecnologia e Inovação (MCTI), Ministério da Educação (MEC), Conselho Nacional de Desenvolvimento Científico e Tecnológico (CNPq), \& Coordenação de Aperfeiçoamento de Pessoal de Nível Superior (CAPES). Programa Ciência sem Fronteiras. Decreto No 7.642 de 13 de dezembro de 2011. Brasília, DF. Disponível em: <http://www.cienciasemfronteiras.gov. $\mathrm{br} /$ documents/214072/0/Decreto+n\%C2\%BA+7642-Ci\%C3\%AAncia-sem-Fronteiras. pdf>. Acesso em: 27 mai. 2013. 
CANAGARAJAH, S. Codemeshing in Academic Writing: Identifying Teachable Strategies of Translanguaging. The Modern Language Journal, 95 (3), p. 401-417, 2011.

CANAGARAJAH, S. \& LIYANAGE, I. Lessons from pre-colonial multilingualism. In: MARTIN-JONES, M; BLACKLEDGE, A. \& CREESE, A. (Eds.) The Routledge Handbook of Multilingualism. London: Routledge, p.49-65, 2012.

CAVALCANTI, M.C. Estudos sobre educação bilingue e escolarização em contextos de minorias linguisticas no Brasil. D.E.L.T.A., Vol. 15, No Especial, p. 385-417, 1999. CAVALCANTI, M.C. "É, eu acho que esse livrinho vai ser muito interessante". Vozes de professores indígenas em um curso de formação. Trabalhos em Linguística Aplicada. Campinas, 44(2), p. 265-276, Jul./Dez., 2005.

CENOZ, J. Defining Multilingualism. In: Annual Review of Applied Linguistics. 33. Cambridge University Press, p. 3-18, 2013.

COTS, J.M; LLURDA, E. \& GARRETT, P. Language policies and practices in the internationalisation of higher education on the European margins: an introduction. In: Journal of Multilingual and Multicultural Development. 35:4, p. 311-317, 2014. FARACO, C.A. (Org.) Estrangeirismos: Guerras em Torno da Língua. São Paulo, SP: Parábola Editorial, 2001.

GARCIA, O. \& SYLVAN, C.E. Pedagogies and Practices in Multilingual Classrooms: Singularities in Pluralities. In: The Modern Language Journal. 95 (3), p. 385-400, 2011.

GIDDENS, A. The Consequences of Modernity. London, UK: Polity Press, 1990.

GORTER,D. \& CENOZ, J. A Multilingual Approach: Conclusions and Future Perspectives: Afterword.In: The Modern Language Journal. 95, iii, p. 442-445, 2011.HALL, S. (Org.) Da diáspora: identidades e mediaçōes culturais. Liv Sovik; Adelaine La Guardia Resende et al. (trad.) Belo Horizonte: Editora UFMG, 2008. HARVEY, D. Condição pós-moderna. São Paulo. Edições Loyola, p. 187-276, 1989. HELLER, M. (Ed.) Bilingualism: a social approach. Basingstoke: Palgrave, 2007. HOBSBAWM, E. J. Nations and Nationalism since 1780. Cambridge: Cambridge University Press, 1990.

JAMESON, F. Postmodernism, or the cultural logic of late capitalism. London, UK: Verso, 1991.

KUMARAVADIVELU, B. A Linguística Aplicada na era da globalização. In: MOITA LOPES, L. P. (Org.) Por uma linguistica indisciplinar. São Paulo: Parábola Editorial, 2006.

KRAMSCH, C. Teaching Foreign Languages in an Era of Globalization: Introduction. In: The Modern Language Journal. 98, 1, p. 296-311, 2014. 
LO BIANCO, J. Domesticating the Foreign: Globalization's Effects on the Place/s of Languages. In: The Modern Language Journal. 98, 1, p. 312-325, 2014.

MARTIN-JONES, M; BLACKLEDGE, A. \& CREESE, A. (Eds.) The Routledge Handbook of Multilingualism. London: Routledge handbook in applied linguistics, 2012. MCNAMARA, T. Multilingualism in Education: A Poststructuralist Critique. In: The Modern Language Journal. 95, p. 430-441, 2011.

MICHAEL-LUNA, S., \& CANAGARAJAH, S. Multilingual Academic Literacies. In: Journal of Applied Linguistics. 4 (1), p. 55-77, 2007.

MOITA LOPES, L. P. Uma linguística aplicada mestiça e ideológica: interrogando o campo como linguista aplicado. In: MOITA LOPES, L. P. (Org.) Por uma linguistica indisciplinar. São Paulo: Parábola Editorial, p.13-44, 2006.

MOITA LOPES, L. P. Linguística aplicada e vida contemporânea. Problematização dos construtos que têm orientado a pesquisa. In: MOITA LOPES, L. P. (Org.) Por uma linguística indisciplinar. São Paulo: Parábola Editorial, p. 85-107, 2006.

MOITA LOPES, L. P. O português no século XXI: cenário geopolítico e sociolinguístico. São Paulo: Parábola Editorial, 2013.

NUNES, J.A. Como pensar a sociedade do conhecimento? In: Pro-Posiçôes. v. 18, n. 1 (52), Jan-abril, p. 29-40, 2007.

OLIVEIRA, L.C. Language Teaching in Multilingual Contexts. In: RBLA. Belo Horizonte. v. 14, n. 2, p. 265-270, 2014.

PAIVA, V.L.M.O. \& PAGANO, A.S. English in Brazil with an outlook on its function as a language of science. In: AMMON, U. (Ed.). The dominance of English as a Language of science. Mouton de Gruyter, p. 425-445, 2001.

RAJAGOPALAN, K. (2001) A polêmica sobre os "estrangeirismos" e o papel dos linguistas no Brasil. 2001. Disponível em: < http://www.comciencia.br/reportagens/ linguagem/ling10.htm>Acesso em: 27 mai. 2013.

RAMPTON, B. Retuning in applied linguistics. In: International Journal of Applied Linguistics. v. 7, n.1, p. 3-25, 1997.

RAMPTON, B. Language and late modernity. Interaction in an urban school. Cambridge: Cambridge University Press, 2006.

RAMPTON, B. Continuidade e mudança nas visões de sociedade em linguística aplicada. In: MOITA LOPES, L. P. (Org.) Por uma linguistica indisciplinar. São Paulo: Parábola Editorial, p.109-28, 2006.

SANTOS, B. S. (Org.) Conhecimento prudente para uma vida decente. Um discurso sobre a ciência revisitado. São Paulo: Cortez, 2004.

SANTOS, B. S. Do pós-moderno ao pós-colonial. E para além de um e outro. In: Conferência de Abertura do VII Congresso Luso-Afro Brasileiro de Ciências Sociais. Coimbra, 2004b. 
SAKAMOTO, M. \& MORALES, M.L. Ethnolinguistic vitality among JapaneseBrazilians: challenges and possibilities, International Journal of Bilingual Education and Bilingualism, 2014. DOI: 10.1080/13670050.2014.964171

SEVERO C.G. \& MAKONI, S.B. Discourses of language in colonial and postcolonial Brazil. In: Language \& Communication. 34, p. 95-104, 2014.

SPOLSKY, B. Language Management. Cambridge: Cambridge University Press, 2009.

SPOLSKY, B. Family language policy: the critical domain. In: Journal of Multilingual and Multicultural Development. v. 33, n. 1, February, p. 3-11, 2012.

VERTOVEC S. Super-diversity and its implications. In: Ethnic and Racial Studies. 29 (6), p. 1024-54, 2007.

WEBER, J.J. \& HORNER, K. Introducing Multilingualism. A social approach. London: Routledge, 2013.

WEI, LI \& MOYER, MELISSA G. (Eds.). The Blackwell Guide to Research Methods in Bilingualism and Multilingualism. USA: Blackwell Publishing, 2008. 403p.

Data de submissão: 15/10/2014. Data de aprovação: 02/03/2015. 